\title{
The Spatial Distribution of Nitrite Concentrations in a Large Drinking Water Distribution System in Finland
}

\author{
Pirjo-Liisa Rantanen ${ }^{*}$, Minna M. Keinänen-Toivola², Merja Ahonen2 ${ }^{2}$ Ilkka Mellin'3, \\ Duoying Zhang4, Tuula Laakso5, Riku Vahala' ${ }^{1}$
}

${ }^{1}$ Department of Built Environment, School of Engineering, Aalto University, Espoo, Finland

${ }^{2}$ Faculty of Technology, Satakunta University of Applied Sciences, Rauma, Finland

${ }^{3}$ Department of Mathematics and Systems Analysis, School of Science, Aalto University, Espoo, Finland

${ }^{4}$ School of Civil Engineering, Heilongjiang University, Harbin, China

${ }^{5}$ Helsinki Regional Environmental Services Authority, Helsinki, Finland

Email: *pirjo.rantanen@aalto.fi

How to cite this paper: Rantanen, P.-L., Keinänen-Toivola, M.M., Ahonen, M., Mellin, I., Zhang, D.Y., Laakso, T. and Vahala, R. (2017) The Spatial Distribution of Nitrite Concentrations in a Large Drinking Water Distribution System in Finland. Journal of Water Resource and Protection, 9, 10261042.

https://doi.org/10.4236/jwarp.2017.98068

Received: May 30, 2017

Accepted: July 15, 2017

Published: July 18, 2017

Copyright $\odot 2017$ by authors and Scientific Research Publishing Inc. This work is licensed under the Creative Commons Attribution International License (CC BY 4.0).

http://creativecommons.org/licenses/by/4.0/

\begin{abstract}
Nitrite in drinking water is a potential health hazard and monitoring its concentrations in distributed water is of paramount importance. When monochloramine is used in secondary disinfection in drinking water distribution systems (DWDSs), nitrite is often formed by nitrification in the biofilm on the inner surface of distribution pipes. This article attempts to identify areas with a risk of increased nitrite concentrations as well as the main reasons leading to nitrite occurrence in a large urban DWDS in Finland using spatial inspection of obligatory monitoring data. Nitrification was found to occur throughout the study area, though nitrite was not increased everywhere. Instead, nitrite was increased close to the water treatment plants (WTPs) and was connected to fresh drinking water than stagnant drinking water. Temperature effects on nitrite concentrations were surprisingly insignificant, even though it is well known that nitrification reactions are affected by temperature. The temperature dependence of ammonium and total residual chlorine was more significant than the dependence of nitrite. The findings of this study emphasize the need to monitor nitrite concentrations close to WTPs.
\end{abstract}

\section{Keywords}

Ammonium, Disinfection with Monochloramine, Distribution

System, Drinking Water, DWDS, Maximum Water Age, Nitrification, Nitrite Concentrations, Residual Total Chlorine, Spatial Inspection, Temperature 


\section{Introduction}

Today, the microbiological quality of drinking water is often ensured by using monochloramine $\left(\mathrm{NH}_{2} \mathrm{Cl}\right)$ as a secondary disinfectant in the drinking water distribution systems (DWDSs). Monochloramine is less reactive than hypochlorous acid or chlorine dioxide, which makes it a good option for disinfection in distribution pipes, especially with high water ages. Monochloramine also forms less trihalomethanes (THMs) and other disinfection by-products (DBPs). However, one disadvantage is the formation of nitrite in the biochemical nitrification of ammonia (Equation (1)), which is formed in the autodecomposition and consumption of monochloramine.

$$
2 \mathrm{NH}_{4}^{+}+3 \mathrm{O}_{2} \rightarrow 2 \mathrm{NO}_{2}^{-}+2 \mathrm{H}_{2} \mathrm{O}+4 \mathrm{H}^{+}
$$

As a result, some water works struggle with nitrification episodes that increase the nitrite concentrations of the distributed drinking water. Concentrations as high as $1 \mathrm{mg} \mathrm{N}^{-1}$ of nitrite have been observed during nitrification episodes in drinking water [1]. A concentration of $50 \mu \mathrm{g} \mathrm{N} \mathrm{l}^{-1}$ of nitrite has been used as an indicator of nitrification in a DWDS by Wilczak et al. [1] and $25 \mu \mathrm{g} \mathrm{N} \mathrm{l}^{-1}$ by Fleming et al. [2]. Nitrite $\left(\mathrm{NO}_{2}^{-}\right)$in drinking water has been linked to health-related problems, e.g. methemoglobinemia and different types of cancer [3]. In Finland the statutory limit for nitrite concentrations in drinking water is $150 \mu \mathrm{g}$ $\mathrm{N} \mathrm{l}^{-1}$ (0.5 mg. $1^{-1}$ of nitrite) [4]. Thus, monitoring nitrite concentrations in DWDSs is extremely important.

Monochloramine was first introduced to secondary disinfection in 1917 [5] and the problems related to incomplete nitrification in a DWDS were reported in 1939 for the first time [6]. Nitrification can cause quality risks in drinking water, such as extra monochloramine consumption [7] [8], oxygen depletion, reduction of $\mathrm{pH}$ and alkalinity, increased numbers of heterotrophic bacteria [1] [9] [10], the formation of N-Nitrosodimethylamine (NDMA) and other DBPs [11], and an increase of autotrophic bacteria [12], as well as the corrosion of several pipe materials [13] [14]. In a recent study, nitrification bacteria were discovered to increase monochloramine consumption significantly via monochloramine cometabolism [15] [16] [17]. Higher temperature increases the growth rate of ammonia and nitrite oxidizing bacteria [10] [18] [19]. Nitrification is more likely to occur in stagnant water [20]. Nitrification prevention methods include disinfection, removal of organics and $\mathrm{pH}$ adjustment [20].

Nitrite concentrations can decrease in several reactions, the most important of which is the biochemical oxidation of nitrite into nitrate (Equation (2)) [21].

$$
2 \mathrm{NO}_{2}^{-}+\mathrm{O}_{2} \rightarrow 2 \mathrm{NO}_{3}^{-}
$$

This article attempts to utilize the obligatory monitoring data collected from a large drinking water distribution system to study the spatial formation of nitrite in relation to the locations of water treatment plants (WTPs), substrate concentration, disinfection, water age, and temperature. When the spatial dynamics of nitrite formation are understood more deeply, we will have a better chance to avoid the risks of increased nitrite concentrations. 


\section{Materials and Methods}

\subsection{Background}

The obligatory monitoring data from a chloraminated DWDS was studied. Nitrification had earlier been observed in the DWDS [22]. In total, 2248 water quality samples were collected between 2010 and 2013 [23] from the system covering two cities (Helsinki and Vantaa) in Finland with a total population of 830,000 [24] and a surface area of $450 \mathrm{~km}^{2}$ [25]. Drinking water was supplied from two WTPs, WTP1, and WTP2, and from a small groundwater plant in the north of the study area (Figure 1(a)). The DWDS consisted of $364.2 \mathrm{~km}$ of water

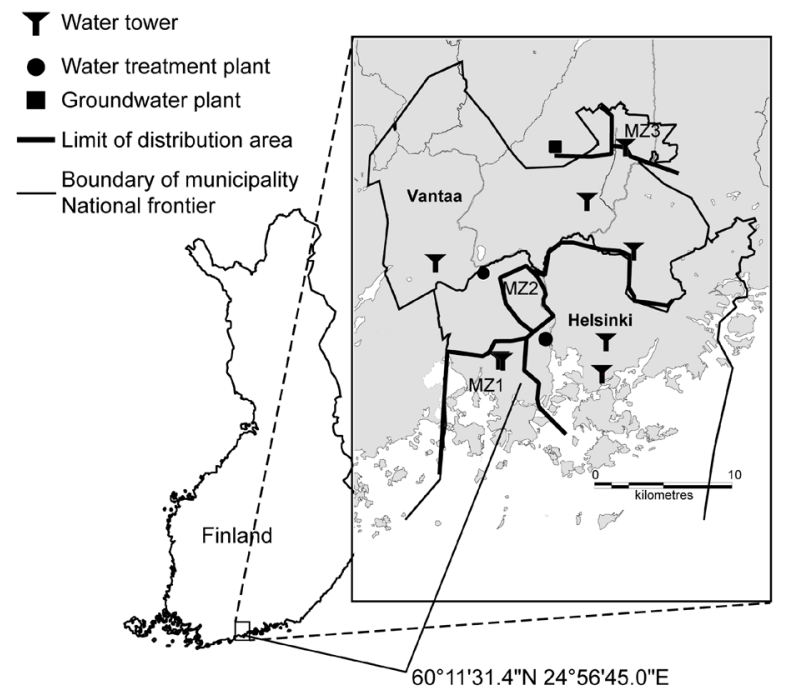

(a)

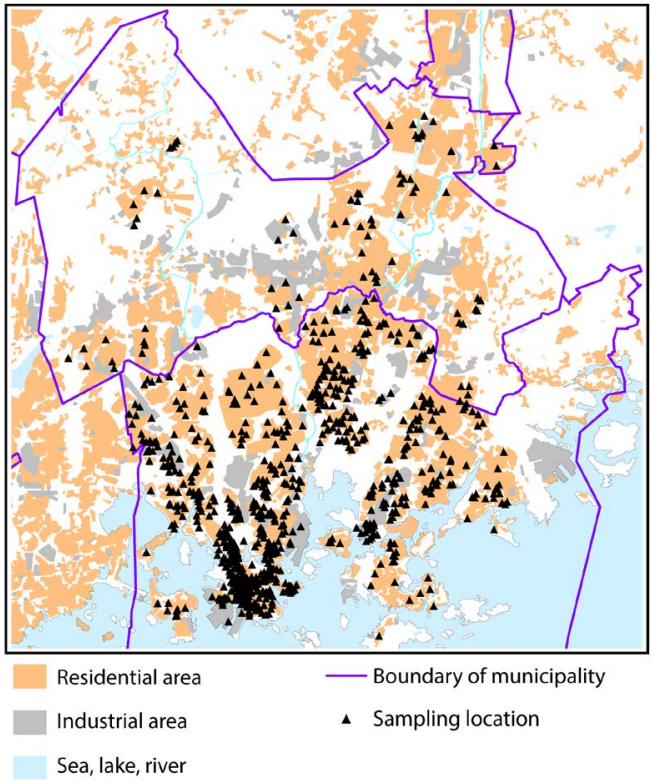

(b)

Figure 1. A map of the study area: (a) The location of the study area, water treatment plants (WTPs), water towers, the groundwater plant, the limits of distribution areas and mixing zones (MZ1-3); (b) The sampling locations of obligatory monitoring. 
mains with larger than $200 \mathrm{~mm}$ diameter in Helsinki, and $255.7 \mathrm{~km}$ of similar mains in Vantaa [26]. In Helsinki the pipe materials were cast iron and steel (99.7\%), and in Vantaa plastic (61.5\%), cast iron and steel (33.3\%), and concrete (6.4\%). The study site consisted of the geographical area defined by the locations of the sampled taps, which were situated in both residential and industrial areas (Figure 1(b)).

\subsection{Water Treatment Processes}

The drinking water in Helsinki and Vantaa is supplied by the Helsinki Region Environmental Services Authority (HSY). The raw water was received from Lake Päijänne, via a $120 \mathrm{~km}$ tunnel. One percent of the annual flow of the lake was used for drinking water production.

The treatment processes of both WTP1 and WTP2 consisted of coagulation-flocculation, sedimentation, filtration, lime addition to raise the $\mathrm{pH}$, ozonation, carbon dioxide addition to increase alkalinity, filtration with granular activated carbon (GAC), and UV disinfection. As a final step, ammonium was added into the drinking water with hypochlorite to form monochloramine. The target of the addition was $0.35-0.4 \mathrm{mg} \mathrm{Cl}_{2} \mathrm{l}^{-1}$ as total residual chlorine and the mass ratio of chlorine and ammonium was approx. 4 . The purpose of monochloramine was to stabilize the distributed water hygienically.

\subsection{Drinking Water Analyses}

The analyses were made at a commercial laboratory, Metropolilab Ltd. [23]. Nitrite, total residual chlorine, and ammonia were analyzed from $96 \%, 82 \%$, and $53 \%$ of the samples, respectively (Table 1). Limits of quantification (LoQ) were 3 $\mu \mathrm{g} \mathrm{N} \mathrm{l}^{-1}, 8 \mu \mathrm{g} \mathrm{N} \mathrm{l}^{-1}$ and $0.03 \mathrm{mg} \mathrm{Cl}_{2} \mathrm{l}^{-1}$, respectively. The ammonia analyses included both species of ammonia and ammonium and the nitrogen from chloramine, all summed up as nitrogen. Temperatures were measured on the sampling sites. The microbiological quality of the water was monitored by several analyses. THMs were analyzed regularly but only a couple of times each year (Table 1).

In Helsinki, drinking water samples were taken only once or very few times from each tap, but several taps close to each other were sampled, leading to geo-

Table 1. The number analyses in obligatory monitoring of drinking water quality in Helsinki and Vantaa between 2.1.2010 and 31.7.2013.

\begin{tabular}{cc}
\hline Analysis & Number of analyses \\
\hline $\mathrm{NO}_{2}^{-}$ & 2151 \\
$\mathrm{NH}_{4}^{+}$ & 1189 \\
$\mathrm{NO}_{3}^{-}$ & 55 \\
Total residual chlorine $\mathrm{Cl}_{2}$ & 1850 \\
Temperature & 2176 \\
Escherichia coli & 1767 \\
Clostridium perfringenss & 954 \\
Coliforms & 1755 \\
THM & 61 \\
\hline
\end{tabular}


graphically dense data (830 sampling locations, Figure 1(b)). In Vantaa, several drinking water samples were taken from each tap, but the tap locations were relatively few in their number, leading to a geographically sparse collection of data (68 sampling locations, Figure 1(b)). The drinking water sampling locations and frequencies were decided by the municipal health authorities.

\subsection{Estimation of Water Age}

A skeleton hydraulic model of the DWDS was devised by a consulting company (Pöyry Finland Ltd., [27]) using Epanet software. The water age was estimated for each of the 898 water-sampling locations as the maximum water age with average flow in the nearest point of the model $\left(t_{\max }\right)$. The minimum calculated $t_{\max }$ for the sampling sites was $1.3 \mathrm{~h}$ and the mean was $41 \mathrm{~h}$.

\subsection{Statistical Methods}

The monitoring data was saved from pdf files into spreadsheets (in MS Excel) and the sampling locations were geocoded. All concentrations below the LoQs were also included in the statistical analysis. The numerical value of LoQ divided by two was used in calculations. Background maps of the area were retrieved from a local internet service portal of the area [28]. The data was processed in Matlab. Descriptive statistics (the minimum, median, and maximum of nitrite concentrations and the median of ammonium concentrations, the concentrations of total residual chlorine, and the water age) were calculated in a $50 \times 50$ $\mathrm{m}^{2}$ grid. The data were interpolated with the inpainting method [29] [30] in order to visualize the spatial distribution of concentrations and water age. The inpainting method has been used for example for filling data gaps concerning upwelling in the Baltic Sea [31] and the land-atmosphere exchange of carbon, water, and energy in the Northern Chihuahua Desert [32].

Contour maps were drawn of the interpolated descriptive statistics in Matlab. Areas where the median of the nitrite was $50 \mu \mathrm{g} \mathrm{N} \mathrm{l}^{-1}$ or higher were highlighted with dotted lines and numbered in all maps. Areas with consistently high nitrite concentration and groups of smaller areas with high nitrite concentration were highlighted. Later in this text these areas are referred as Nitrite Formation Areas (NFAs), followed by a number (NFA1-NFA10).

The mean, median, minimum, and maximum of nitrite, ammonium and the total residual chlorine concentrations in the drinking water were calculated for the cities of Helsinki and Vantaa. The Student's t-test was used to compare differences in nitrite, ammonium and total residual chlorine concentrations between the cities.

\section{Results}

\subsection{Nitrite Formation}

The spatial inspection revealed that nitrite was formed close to the WTPs, which can be observed in both minimum, median and maximum concentrations of nitrite (Figures 2(a)-(c)). Nitrite concentrations formed distinct areas where ni- 


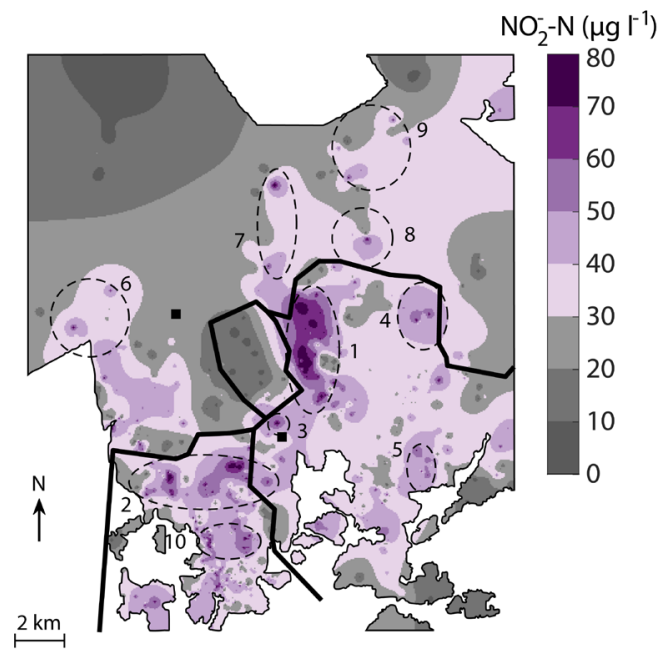

(a)

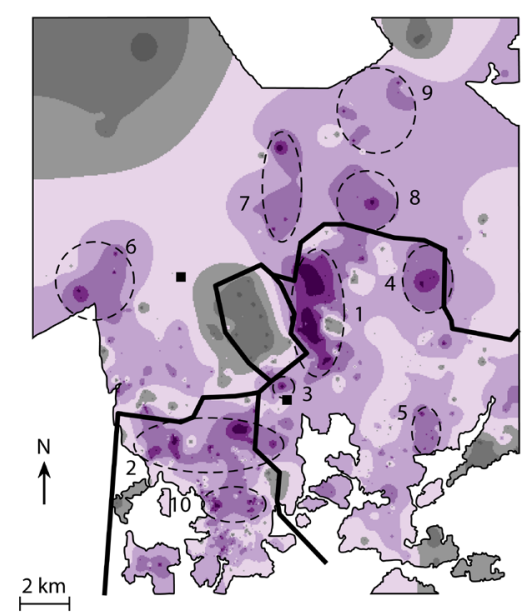

(b)

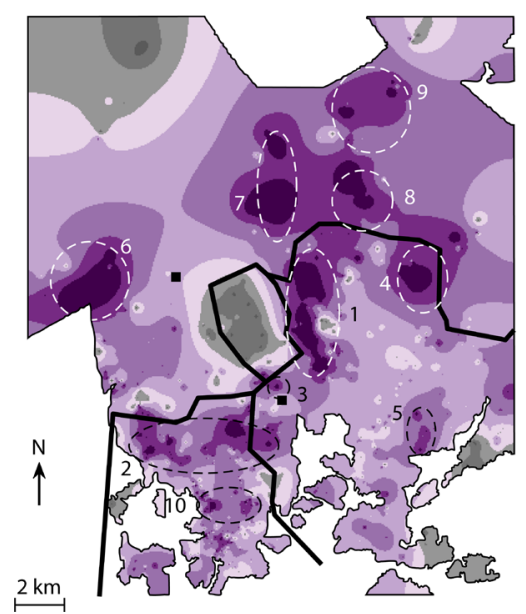

(c)

Figure 2. The (a) minimum, (b) median, and (c) maximum of nitrite concentrations in the obligatory monitoring water analyses between January 2010 and July 2013 in $50 \mathrm{~m} \times$ $50 \mathrm{~m}$ squares. The Nitrite Formation Areas (NFAs) have been highlighted by dotted lines. The borders of the main distribution areas are shown by thick lines. The WTPs are shown by squares. 
trite occurred (defined as nitrite concentration above $50 \mu \mathrm{g} \mathrm{N}^{-1}$ in the medians

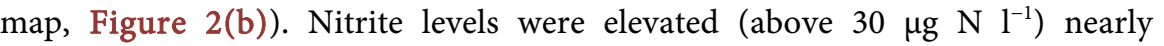
through-out the entire study area.

Two large Nitrite Formation Areas (NFAs) were located close to WTP1 (Figures 2(a)-(c)), one of them (NFA1) in the main distribution area of WTP1 and another (NFA2) in the area in which waters from WTP1 and WTP2 were mixed (mixing zone MZ1). It is notable that nitrite occurred in a small area closer than $1 \mathrm{~km}$ to WTP1 (NFA3). The highest nitrite concentrations occurred in NFA1, which was the largest consistent area of nitrite occurrence in the study area. Farther away from WTP1, nitrite occurred in NFAs 4 and 5. The pattern of the concentrations and the level of the concentrations was rather similar in the distribution area of WTP1 and the mixing area in all maps, Figures 2(a)-(c), reflecting the sampling strategy in which few drinking water samples were taken from each tap (see also Section 2.3 in Materials and Methods).

In the distribution area of WTP2, nitrite occurred in four sites (NFAs 6 - 9), all of which were at some distance from WTP2. The minimum and maximum maps differed considerably from each other. In the city of Vantaa, which formed most of the distribution area of WTP2, several drinking water samples were taken from each tap, giving more variation to each geographical location. This suggested that there were underlying reasons for nitrite occurrence resulting in a variation in nitrite concentrations within the same locations. For example, at Myyrmäki Sports hall, in NFA6, 21 drinking water samples were taken and nitrite concentrations varied between 30 and $100 \mu \mathrm{g} \mathrm{N} \mathrm{l}^{-1}$.

The nitrite concentrations decreased from the highest values towards the northern and southern extremities of the DWDS. In the northern extremity, the lowest nitrite concentrations were below the limit of quantification. For example, at Katriina hospital, $9.2 \mathrm{~km}$ north of WTP2, 34 drinking water samples were taken, and all nitrite concentrations were below the LoQ $\left(<3 \mu \mathrm{g} \mathrm{N}^{-1}\right)$. In the northeast corner of the study area, low nitrite concentrations occurred in the distribution area of the small groundwater plant. A large area of low nitrite concentrations, consisting mostly of the northern part of the mixing zone (MZ2), occurred between WTP1 and WTP2. In addition, nitrite was low in a few scattered spots that were clearly smaller than the nitrite formation areas (Figures 2(a)-(c)).

NFA10 was situated inside the mixing zone (MZ1) (Figure 2), and had one of the highest population densities in the whole study area with 9600 inhabitants per square kilometer in 2013 [33]. On the other hand, in mixing zone MZ2, where nitrite concentrations were low, the population densities were also low with 1800 inhabitants per square kilometer in 2013 [33]. The mean population density of the entirety of Helsinki was 2900 inhabitants per square kilometer in 2013 [33].

The nitrite concentrations differed slightly, but significantly, between the two cities (difference $4 \mu \mathrm{g} \mathrm{N} \mathrm{l}^{-1}, \mathrm{t}=3.17, \mathrm{p}=0.002$, see also Table 2). The lower concentrations in Vantaa are explained by a large share of concentrations below the $\operatorname{LoQ}\left(<3 \mu \mathrm{g} \mathrm{N}^{-1}\right), 12.6 \%$, while in Helsinki the share was only $1.9 \%$. 
Table 2. The nitrite, ammonium, and total residual chlorine concentrations in the cities of Helsinki and Vantaa.

\begin{tabular}{ccccc}
\hline & & Mean & Median & Range \\
\hline $\mathrm{NO}_{2}^{-}$ & All data & 45 & 46 & $<3-128$ \\
& Helsinki & 46 & 46 & $<3-100$ \\
& Vantaa & 41 & 43 & $<3-128$ \\
$\mathrm{NH}_{4}^{+}$ & All data & 43 & 38 & $<8-148$ \\
$\mathrm{Mg} \mathrm{N} \mathrm{I}^{-1}$ & Helsinki & 44 & 40 & $<8-132$ \\
& Vantaa & 37 & 29 & $<8-148$ \\
$\mathrm{Cl}_{2}$ & All data & 0.12 & 0.11 & $<0.03-0.54$ \\
$\mathrm{mg} \mathrm{Cl}_{2} \mathrm{l}^{-1}$ & Helsinki & 0.12 & 0.11 & $<0.03-0.54$ \\
& Vantaa & 0.10 & 0.06 & $<0.03-0.31$ \\
\hline
\end{tabular}

\subsection{The Relation of Other Variables to Nitrite Concentrations}

When the maps of nitrite concentrations and maximum water age were compared, it was noted that nitrite occurrence was more often related to fresh than stagnant water (Figures 2(a)-(c) and Figure 3(a)). Nitrite concentrations did not have straightforward dependence on maximum water age and nitrite did not occur specifically in areas where maximum water age was low or below any set value. Rather, nitrite was formed rarely when maximum water age was high (above 48 hours). In three NFAs (highlighted in Figure 3(a)), the maximum water age was less than $24 \mathrm{~h}$ (NFAs 1, 6 and 9), in six NFAs it was $24-48 \mathrm{~h}$ (NFAs 2, 3, 5, 7, 9 and 10), and in one NFA it was over 48 h (NFA4). The observed likelihood of nitrite occurrence was the highest with a maximum water age between $24 \mathrm{~h}$ and $48 \mathrm{~h}$.

Ammonium and nitrite concentrations were above $30 \mu \mathrm{g} \mathrm{N}^{-1}$ in areas that were geographically remarkably similar (Figures 2(a)-(c) and Figure 3(b)). Some resemblance can be found in the northern part of the maps; the NFAs 6 - 9 have more or less the same location as the peaks of ammonium. On closer inspection, this appears to be only the result of the sampling locations.

While the spread of nitrite was similar to that of ammonium, it was spread over a slightly larger area, indicating that, even though ammonium was below 30 $\mu \mathrm{g} \mathrm{N}^{-1}$, nitrite was still forming from it, reducing the ammonium concentrations even further towards the ends of the mains. In the southern half of the study area, the highest concentrations of ammonium and nitrite were in different spatial locations, which can be explained by ammonium being the substrate for nitrite formation.

Nitrite occurrence did not overlap consistently with high residual total chlorine concentrations nor with low residual total chlorine concentrations, but nitrite occurred on the edges of high and low residual total chlorine concentrations. Presumably, the monochloramine concentrations were so low that they did not prevent nitrite formation. The medium-level nitrite concentrations in 


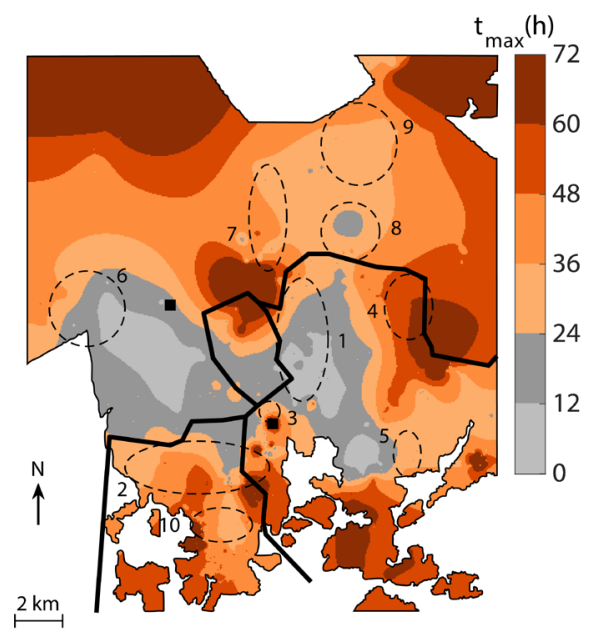

(a)

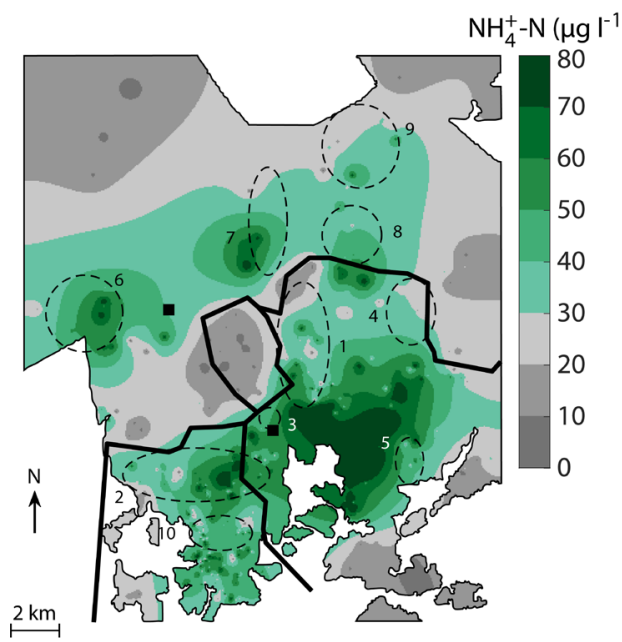

(b)

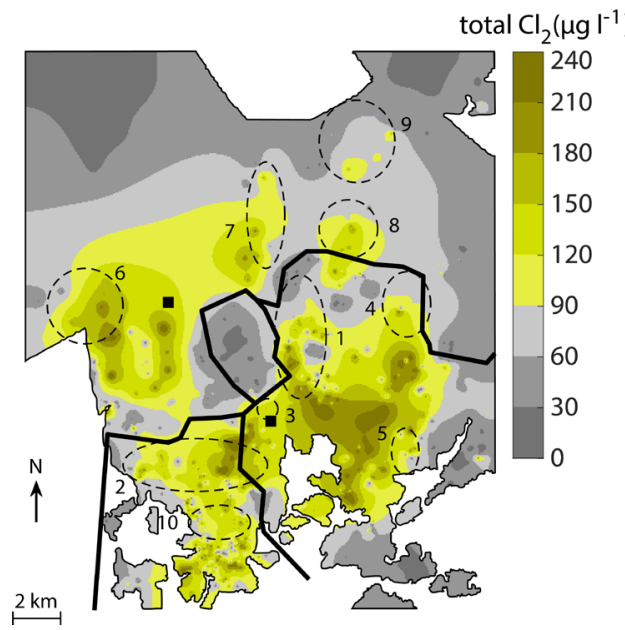

(c)

Figure 3. Maps of the medians of (a) water age, (b) ammonia and (c) total residual chlorine concentrations in the obligatory monitoring water analyses between January 2010 and July 2013 in $50 \mathrm{~m} \times 50 \mathrm{~m}$ squares. The areas of nitrite formation (NFAs) have been highlighted by dotted circles (see also Figure 2). 
the WTP1 distribution area, where residual total chlorine was high, indicate that some nitrification occurred, thus it was not prevented.

Ammonium and total residual chlorine concentrations in the obligatory monitoring data differed significantly between the cities of Helsinki and Vantaa (the difference of ammonium: $7 \mu \mathrm{g} \mathrm{N} \mathrm{l^{-1 }}, \mathrm{t}=3.22, p=0.001$ and the difference of total residual chlorine: $21 \mu \mathrm{g} \mathrm{Cl}_{2} \mathrm{l}^{-1}, \mathrm{t}=3.54, p<0.001$, see also Table 2). Both concentrations were lower in the data from the city of Vantaa. The shares of concentrations below the LoQ explained both of the differences; in Vantaa the shares were $21.1 \%$ (ammonium) and 38.5\% (total residual chlorine) and in Helsinki they were $7.4 \%$ and $18.7 \%$, respectively.

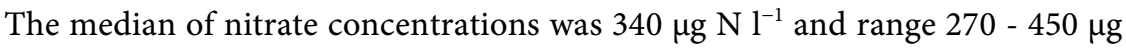
$\mathrm{N} \mathrm{l}^{-1}$. The nitrate analyses were, however, too few to enable statistical analysis (Table 1).

The monochloramine concentration (initially $0.35-0.4 \mathrm{mg} \mathrm{Cl}_{2} \mathrm{l}^{-1}$ in freshly produced drinking water) was able to keep the microbiological quality of the distributed water: the maximum of $E$. coli was $<1 \mathrm{mpn}(100 \mathrm{ml})^{-1}$, coliforms were on one occasion $74 \mathrm{mpn}(100 \mathrm{ml})^{-1}$, the maximum on other occasions was $4 \mathrm{mpn}(100 \mathrm{ml})^{-1}$, and Clostridium perfringens maximum was $1 \mathrm{cfu}(100 \mathrm{ml})^{-1}$. The medians were $<1 \mathrm{mpn}(100 \mathrm{ml})^{-1},<1 \mathrm{mpn}(100 \mathrm{ml})^{-1}$ and $<1 \mathrm{cfu}(100 \mathrm{ml})^{-1}$, respectively.

\subsection{Nitrite and Temperature}

According to this data, low temperature did not prevent nitrite formation (Figure 4(a)). Nitrite concentrations in both temperatures above and below $9^{\circ} \mathrm{C}$ were spatially relatively similar. At temperatures above $9^{\circ} \mathrm{C}$, the highest nitrite concentrations (Figure 4(b)) occurred closer to the WTPs, especially WTP1, than they did at temperatures below $9^{\circ} \mathrm{C}$. Below $9^{\circ} \mathrm{C}$, the elevated nitrite concentrations were spread to a slightly larger area than above $9^{\circ} \mathrm{C}$. The temperature was measured as the sample temperature onsite. The mean of temperatures was $8.7^{\circ} \mathrm{C}$, the median $8.3^{\circ} \mathrm{C}$ and the range $3.3^{\circ} \mathrm{C}-15.5^{\circ} \mathrm{C}$.

The behavior of ammonium and residual total chlorine in relation to temperature was very different from nitrite; they both occurred in significantly diminished areas above $9^{\circ} \mathrm{C}$ compared to below $9^{\circ} \mathrm{C}$ (Figures $4(\mathrm{c})$-(f)). Both ammonium and residual total chlorine formed areas that showed high and low concentrations. It is well known that monochloramine dissociates or reacts faster at higher temperatures so it is clear why there is less total residual chlorine at higher temperatures. In addition, ammonia is nitrified faster at higher temperatures via Monod kinetics.

\section{Discussion}

\subsection{Nitrite Concentrations}

Compared to the water supplied from the WTPs, the nitrite concentrations in the DWDS were elevated in the study area. In the minimum concentrations map approx. half of the study area had a concentration of nitrite above $30 \mu \mathrm{g} \mathrm{N} \mathrm{l}^{-1}$, in 

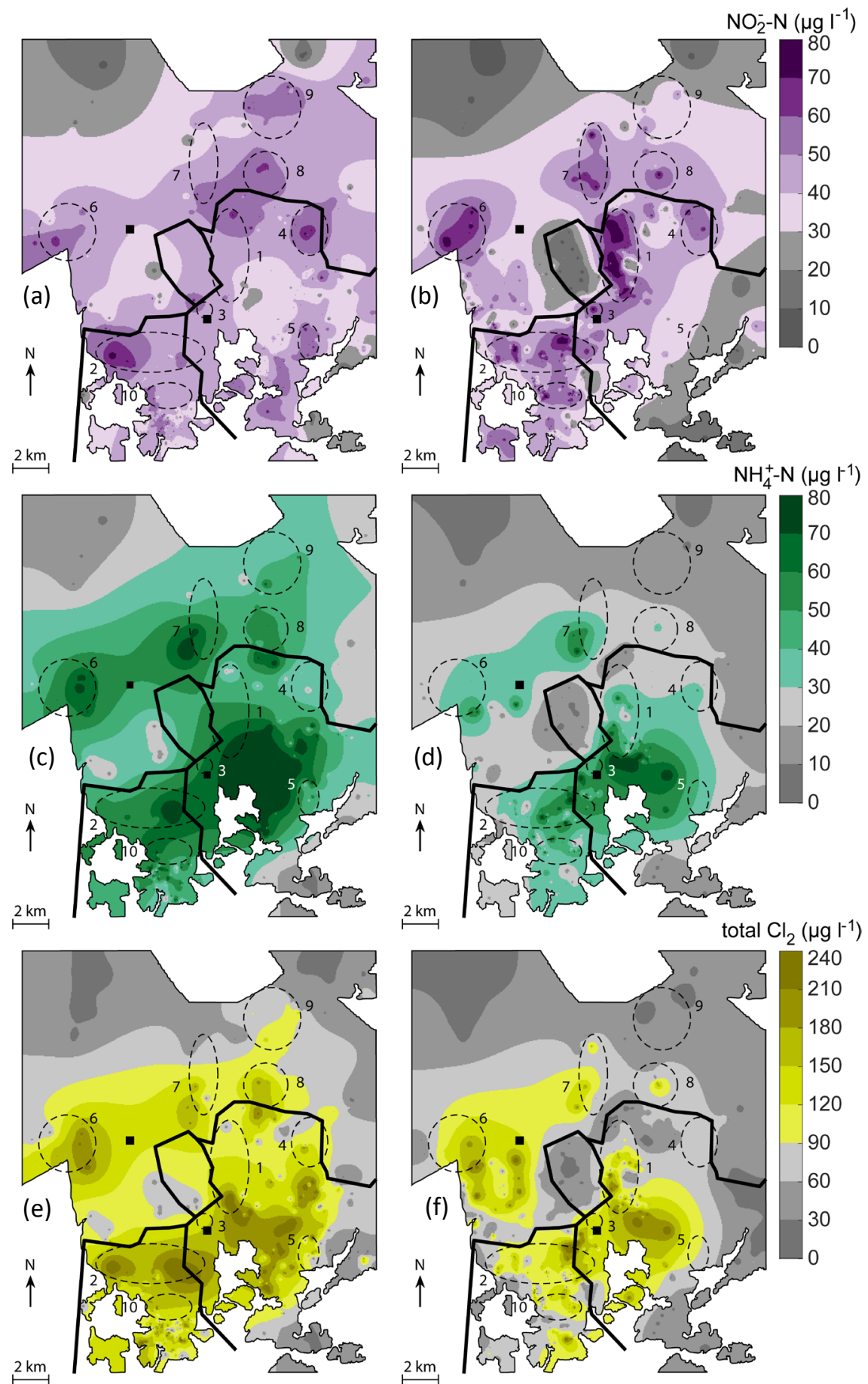

Figure 4. Nitrite, ammonium and residual total chlorine below a temperature of $9^{\circ} \mathrm{C}$ (images a, c, and e, respectively) and above $9^{\circ} \mathrm{C}$ (images b, $d$, and $\mathrm{f}$, respectively). The concentrations are from the obligatory monitoring water analyses between January 2010 and July 2013 in $50 \mathrm{~m} \times 50 \mathrm{~m}$ squares. The areas of nitrite formation (NFAs) have been highlighted by dotted line (see also Figure 2 ).

the median map it was above $40 \mu \mathrm{g} \mathrm{N} \mathrm{l}^{-1}$ and in the maximum map it was above $50 \mu \mathrm{g} \mathrm{N} \mathrm{l}^{-1}$ (Figures 2 (a)-(c), respectively). The median nitrite concentration of water supplied from WTP1 was $9 \mu \mathrm{g} \mathrm{l}^{-1}$ (range: $2-23 \mu \mathrm{g} \mathrm{l}^{-1}$ ) and from 


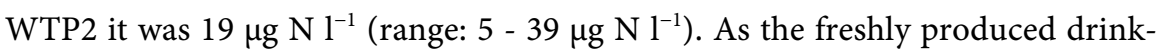
ing water contains all the nitrite from raw water and the treatment process, we can conclude that nitrite was also formed in the distribution network.

It was dubious why the nitrite concentrations were so high in the freshly produced drinking water supplied from the WTPs. In 2015, it was observed that nitrite concentrations were already raised in the sampling line leading to the onsite laboratory at WTP2 [34]. The concentrations of nitrite in the water before the

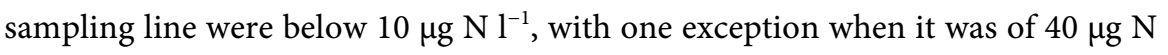
$\mathrm{l}^{-1}$. All the samples of freshly produced water at WTP2 were taken from this sampling line during our research period (2010 to 2013). This indicates that the nitrite concentrations of freshly produced drinking water were even somewhat exaggerated during 2010-2013, and that nitrite primarily was formed in the distribution pipes.

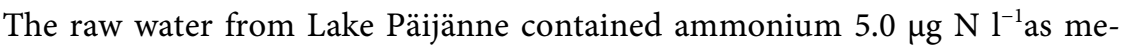
dian and $230 \mu \mathrm{g} \mathrm{N} \mathrm{l}^{-1}$ of nitrite plus nitrate between 2000 and 2013 [35]. Unfortunately, nitrite was not analyzed separately. A fraction of the nitrite in the freshly produced drinking water may have come from the nitrite in raw water. The ammonium in raw water most probably did not end up in the freshly produced drinking water because of the granular activated carbon (GAC) filtration in the treatment process. The GAC filters grow a biofilm on the surface of the carbon granules and the biofilm may have nitrification activity [36]. The monochloramine was added as the last step of the treatment process after the GAC filtration, thus, the nitrification of monochloramine in the GAC filtration was not possible. Consequently, most of the nitrite in the drinking water distributed to customers originated from added chloramine.

No nitrite concentrations exceeded the current Finnish statutory limit of 150 mg. $\mathrm{l}^{-1}\left(0.5 \mu \mathrm{g} \mathrm{N} \mathrm{l^{-1 }}\right.$ of nitrite, [4] [37]). However, the earlier Finnish limit of 30 mg. $\mathrm{l}^{-1}\left(0.1 \mu \mathrm{g} \mathrm{N} \mathrm{l}^{-1}\right.$ of nitrite, [38]), was exceeded in $72 \%$ of the analyzed drinking water samples. The latter, tighter, statutory limit for nitrite was still in use, for example, in Denmark when this article was written [39]. However, in the Danish drinking water, nitrite originates mostly from groundwater and chloramine is not used in the secondary disinfection. The nitrite concentrations are lower in the distributed water than in water supplied from the WTPs, thus nitrite is not formed in distribution but oxidized into nitrate [40].

All in all the observed concentrations of nitrite in the study area were low compared to the highest concentrations in nitrification episodes $\left(1 \mathrm{mg} \mathrm{N}^{-1}\right)$ that were noted by Wilczak et al. [1]. It is obvious that the low monochloramine concentration limited the nitrite concentrations. The mean initial monochloramine concentration was $0.16 \mathrm{mg} \mathrm{N}^{-1}$ as ammonium and the observed mean of nitrite concentrations was $28 \%$ of this and the maximum was $80 \%$. Hypothetically, if the monochloramine dose had been high enough, it could have inhibited ammonium oxidation (Equation (1)) and thus nitrite formation close to the WTPs and close to the dense population. This would still have led to nitrite formation after monochloramine depletion and higher nitrite concentrations in the 
extremities of the distribution areas. In this case, the maximum nitrite concentrations would have been much higher in relation to the observed monochloramine concentrations.

Wilczak et al. [1] observed elevated nitrite concentrations during both winter and summer, though nitrification incidents were higher during summer or at temperatures above $15^{\circ} \mathrm{C}$. In our study, increased nitrite concentrations were observed both below and above $9^{\circ} \mathrm{C}$.

Vahala et al. [22] noticed nitrite levels of $50 \mu \mathrm{g} \mathrm{N} \mathrm{I}^{-1}$ in the drinking water in the distribution area of WTP1 during the summer months after the commissioning of GAC filtration at WTP1 in 1998. The filtration is still at use in WTP1 and the nitrite concentrations are similar to those observed by Vahala et al. [22]. Obviously, nitrite formation has not increased since but has stayed at more or less the same level. In another study, Vahala et al. [41] speculated that decreased organic concentrations favored autotrophic bacteria that do not use organic matter as an energy source. Unfortunately, the materials of our article did not have enough analyses of organic matter (total organic carbon) to be able to study this phenomenon further. Skadsen [9] also noticed similar nitrification episodes after GAC was commissioned in Ann Arbor, Michigan.

\subsection{Nitrification}

The problem with nitrite in drinking water is not nitrification itself, but nitrite formation as a result of the two nitrification reactions: ammonia oxidation into nitrite (Equation (1)) and nitrite oxidation into nitrate (Equation (2)). The observed nitrite concentrations were a result of these two reactions and the relative balance between them. Harrington et al. [20] pointed out that nitrification would have a better chance of occurring in stagnant water further from the WTP rather than close to WTP. On the other hand, in our data the nitrite was formed quite close to the WTPs. In the stagnant water far from the WTPs, nitrite had a tendency to be low. It is possible that the low initial monochloramine concentration $\left(0.35-0.4 \mathrm{mg} \mathrm{Cl}_{2} \mathrm{l}^{-1}\right)$ in the freshly produced drinking water was the reason for this. For example, in the research done by Wilczak et al. [1] in the U.S., 74\% of the initial monochloramine concentrations were between 1.0 and $3.0 \mathrm{mg} \mathrm{Cl}_{2}$ $\mathrm{l}^{-1}$ and only a few were below $0.5 \mathrm{mg} \mathrm{Cl}_{2} \mathrm{l}^{-1}$.

Nitrifying bacteria and nitrification activity have been found in Finnish DWDSs in spite of low water temperature [42] [43]. Another Finnish survey found the nitrite and nitrate concentrations in Finnish drinking water were $<0.03-0.1 \mathrm{mg} \mathrm{N}^{-1}$ and $1-3 \mathrm{mg} \mathrm{N}^{-1}$, respectively, in 1999-2007 [44]. Our results are well in line with these studies.

Wolfe et al. [10] discovered that monochloramine levels of 1 to $2 \mathrm{mg} \mathrm{Cl}_{2} \mathrm{l}^{-1}$ should be sufficient to eliminate nitrifiers [10]. Fleming et al. [45] calculated that below a theoretical threshold concentration of total residual chlorine of $1.6 \mathrm{mg}$ $\mathrm{Cl}_{2} \mathrm{I}^{-1}$, nitrification would occur depending on the ratio of total chlorine and ammonia and above the threshold concentration, no nitrification would occur, independent of ammonia concentrations. According to the nitrification poten- 
tial curves by Fleming et al. [45], nitrification is prevented when the mass ratio of total chlorine and ammonia is above $8: 1 \mathrm{mg} \mathrm{Cl}: \mathrm{mg} \mathrm{N}$. In our research, the total residual chlorine in the water supplied from the WTPs was $0.35-0.4 \mathrm{mg}$ $\mathrm{Cl}_{2} 1^{-1}$, which meant that nitrification would depend on the mass ratio of total chlorine and ammonia. In our study, the median of the ratio in the distributed drinking water was $2.9 \mathrm{mg} \mathrm{Cl}_{2}: \mathrm{mg} \mathrm{N}$ (a range of 0.14 to $7.7 \mathrm{mg} \mathrm{Cl}_{2}: \mathrm{mg} \mathrm{N}$ ), indicating that the monochloramine concentration was theoretically insufficient to prevent nitrification in the distribution system.

Speitel et al. [46] suggested that THMs inhibit nitrification. This type of inhibition was unlikely in the study area, because all of the 61 samples of THM analyses showed concentrations below the LoQ. Ammonia oxidizing bacteria (AOB) are capable of biodegrading THMs in their metabolism [47] and it is possible that the low THM concentrations in the customers' taps is the result of this if the freshly produced water had any THMs. However, this is not likely; because the treatment process included two steps of organics removal (coagulation settling and ozonation GAC filtration) before the monochloramine was added. In addition, monochloramine does not form THMs to the same extent as free chlorine [48].

\section{Conclusion}

The research revealed that nitrification occurred close to the WTPs and increased nitrite concentrations were related to fresh water rather than stagnant water. The low initial monochloramine concentrations were not high enough to prevent nitrification, but limited the maximum nitrite concentrations. Low temperature did not significantly inhibit nitrification or nitrite formation. The temperature dependence of ammonium and total residual chlorine was more significant than the temperature dependence of nitrite. The findings of this study emphasize that nitrite concentrations should be monitored close to the WTPs; focusing on stagnant water is not sufficient.

\section{Acknowledgements}

We thank the foundation of Maa- ja vesitekniikan tuki ry., for financing the research. We also thank HSY (Helsinki Region Environmental Services Authority) for their cooperation and for providing the obligatory monitoring data, as well as their internal monitoring data for our use. We are grateful to Ritva Laitala from Pöyry Finland Ltd. for providing the water age modeling results. We express our gratitude to Dr. Joseph Guillaume from Aalto University for his invaluable comments.

\section{References}

[1] Wilczak, A., Jacangelo, J.G., Marcinko, J.P., Odell, L.H., et al. (1996) Occurrence of Nitrification in Chloraminated Distribution Systems. Journal of the American Water Works Association, 88, 74.

https://www.awwa.org/publications/journal-awwa/abstract/articleid/13580.aspx 
[2] Fleming, K.K., Harrington, G.W. and Noguera, D.R. (2008) Using Nitrification Potential Curves to Evaluate Full-Scale Drinking Water Distribution Systems. Journal of the American Water Works Association, 100, 92-103.

https://www.awwa.org/publications/journal-awwa/abstract/articleid/15985.aspx

[3] National Research Council (2006) Drinking Water Distribution Systems. National Academies Press, Washington DC.

[4] Finnish Ministry of Social Affairs and Health (2015) Sosiaalija terveysministeriön asetus talousveden laatuvaatimuksista ja valvontatutkimuksista. 1352/2015. http://www.finlex.fi/fi/laki/alkup/2015/20151352

[5] Race, J. (1918) Chlorination of Water. 1st Edition, John Wiley Sons, Inc., London.

[6] Larson, T.E. (1939) Bacteria, Corrosion and Red Water. Journal of the American Water Works Association, 31, 1186-1196. http://www.jstor.org/stable/41232270

[7] Margerum, D.W., Schurter, L.M., Hobson, J. and Moore, E. (1994) Water Chlorination Chemistry: Nonmetal Redox Kinetics of Chloramine and Nitrite Ion. Environmental Science \& Technology, 28, 331-337.

[8] Valentine, R.L. (1982) The Disappearance of Chloramines in the Presence of Bromide and Nitrite. Ph.D. Dissertation, University of California, Berkeley, United States. http://search.proquest.com/docview/303216618

[9] Skadsen, J. (1993) Nitrification in a Distribution System. Journal of the American Water Works Association, 85, 95.

https://www.awwa.org/publications/journal-awwa/abstract/articleid/13062.aspx

[10] Wolfe, R.L., Lieu, N.I., Izaguirre, G. and Means, E.G. (1990) Ammonia-Oxidizing Bacteria in a Chloraminated Distribution System: Seasonal Occurrence, Distribution, and Disinfection Resistance. Applied and Environmental Microbiology, 56, 451. http://aem.asm.org/content/56/2/451.full.pdf+html

[11] Wang, W., Ren, S., Zhang, H., Yu, J., An, W., Hu, J. and Yang, M. (2011) Occurrence of Nine Nitrosamines and Secondary Amines in Source Water and Drinking Water: Potential of Secondary Amines as Nitrosamine Precursors. Water Research, 45, 4930-4938.

[12] AWWA Staff (2006) Fundamentals and Control of Nitrification in Chloraminated Drinking Water Distribution Systems. 2nd Edition, American Water Works Association, Denver, CO.

[13] Meincke, M., Krieg, E. and Bock, E. (1989) Nitrosovibrio spp., the Dominant Ammonia-Oxidizing Bacteria in Building Sandstone. Applied and Environmental Microbiology, 55, 2108-2110. http://aem.asm.org/content/55/8/2108.full.pdf + html

[14] Huang, Y.H. and Zhang, T.C. (2005) Effects of Dissolved Oxygen on Formation of Corrosion Products and Concomitant Oxygen and Nitrate Reduction in Zero-Valent Iron Systems with or without Aqueous $\mathrm{Fe}^{2+}$. Water Research, 39, 1751-1760.

[15] Maestre, J.P., Wahman, D.G. and Speitel, G.E. (2013) Monochloramine Cometabolism by Nitrosomonas europaea under Drinking Water Conditions. Water research, 47, 4701-4709.

[16] Maestre, J.P., Wahman, D.G. and Speitel Jr., G.E. (2016) Monochloramine Cometabolism by Mixed-Culture Nitrifiers under Drinking Water Conditions. Environmental Science \& Technology, 50, 6240-6248.

https://doi.org/10.1021/acs.est.5b05641

[17] Wahman, D.G., Maestre, J.P. and Speitel Jr., G.E. (2016) Monochloramine Cometabolism by Nitrifying Biofilm Relevant to Drinking Water. Journal of the American Water Works Association, 108, E362-E373.

https://doi.org/10.5942/jawwa.2016.108.0092 
[18] Ike, N.R., Wolfe, R.L. and Means, E.G. (1988) Nitrifying Bacteria in a Chloraminated Drinking Water System. Water Science and Technology, 20, 441-444. http://wst.iwaponline.com/content/20/11-12/441

[19] Wolfe, R.L., Means, E.G., Davis, M.K. and Barrett, S.E. (1988) Biological Nitrification in Covered Reservoirs Containing Chloraminated Water. Journal of the American Water Works Association, 80, 109-114. https://www.awwa.org/publications/journal-awwa/abstract/articleid/12087.aspx

[20] Harrington, G.W., Noguera, D.R., Kandou, A.I. and Vanhoven, D.J. (2002) PilotScale Evaluation of Nitrification Control Strategies. Journal of the American Water Works Association, 94, 78-89. https://www.awwa.org/publications/journal-awwa/abstract/articleid/14687.aspx

[21] Ward, B.B., Arp, D.J. and Klotz, M.G. (2011) Nitrification. ASM Press, Washington DC.

[22] Vahala, R. and Laukkanen, R. (1998) Nitrification in GAC-Filtered, UV-Disinfected and Chloraminated Distribution System. Proceedings of Specialized Conference on Drinking Water Distribution with or without Disinfectant Residual, Mülheim an der Ruhr, Germany, 28-30 September 1998.

[23] Kalso, S. (2013) Drinking Water Analysis Reports 2010-2013. Metropolilab, HSY Vesi, Helsinki.

[24] Statistics Finland (2015) Kuntien Avainluvut. http://www.stat.fi

[25] NLS (2013) Maanmittaus 2013. National Land Survey of Finland, Helsinki. http://www.maanmittauslaitos.fi/en

[26] Helsinki Region Environmental Services Authority HSY (2017) Verkon operatiivinen raportointi. Database Helsinki.

[27] Laitala, R. (2015) Water Age with Mean Daily Consumption in Present Situation in the Calculation Model of HSY's Drinking Water Distribution System. Excel File Pöyry Finland Oy, Vantaa.

[28] Linna, T. and Tolkki, T. (2012) Helsinki Region Map [Map]. City Engineer's Office of Helsinki, Helsinki. http://kartta.hel.fi/avoindata/

[29] D’Errico, J. (2012) Inpaint_nans. Interpolates (\& Extrapolates) NaN Elements in a 2d Array.

http://www.mathworks.com/matlabcentral/fileexchange/4551-inpaint-nans

[30] Garcia, D. (2010) Robust Smoothing of Gridded Data in One and Higher Dimensions with Missing Values. Computational Statistics \& Data Analysis, 54, 11671178.

[31] Sproson, D. and Sahlee, E. (2014) Modelling the Impact of Baltic Sea Upwelling on the Atmospheric Boundary Layer. Tellus A: Dynamic Meteorology and Oceanography, 66, Article ID: 24041. https://doi.org/10.3402/tellusa.v66.24041

[32] Jaimes Hernandez, A. (2014) Furthering Our Understanding and Scaling Patterns and Controls of Land-Atmosphere Carbon, Water and Energy Exchange in a Chihuahuan Desert Shrubland with Novel Cyberinfrastructure. Ph.D. Dissertation, The University of Texas at El Paso, Texas. http://search.proquest.com/docview/1561147292

[33] Tikkanen, T. (2014) Helsinki by District 2014. City of Helsinki Urban Facts, Helsinki, Finland. http://www.hel.fi/tietokeskus

[34] Helsinki Region Environmental Services Authority HSY (2016) Pitkäkoski, talousvesi 2014-2016. Helsinki.

[35] Finnish Environment Institute (2013) Oiva Database. Finnish Environment Institute. https://wwwp2.ymparisto.fi/scripts/oiva.asp 
[36] Feben, D. (1935) Nitrifying Bacteria in Water Supplies. Journal of the American Water Works Association, 27, 439-447. http://www.jstor.org/stable/41226283

[37] European Council (1998) Council Directive 98/83/EC, of 3 November 1998, on the Quality of Water Intended for Human Consumption. L 330/32. http://eur-lex.europa.eu/legal-content/EN/TXT/?uri=CELEX:31998L0083

[38] Finnish Ministry of Social Affairs and Health (1994) Sosiaali-ja terveysministeriön päätös talousveden laatuvaatimuksista ja valvontatutkimuksista. 74/1994. http://www.finlex.fi/fi/laki/alkup/1994/19940074

[39] Danish Environmental Ministry (2015) Bekendtgørelse om vandkvalitet og tilsyn med vandforsyningsanlæg. BEK nr. 1310, j.nr. NST-400-00073. http://www.retsinformation.dk

[40] Schullehner, J., Stayner, L. and Hansen, B. (2017) Nitrate, Nitrite, and Ammonium Variability in Drinking Water Distribution Systems. International Journal of Environmental Research and Public Health, 14, 276. https://doi.org/10.3390/ijerph14030276

[41] Vahala, R., Niemi, R.M., Kiuru, H. and Laukkanen, R. (1998) The Effect of GAC Filtration on Bacterial Regrowth and Nitrification in a Simulated Water Main. Journal of Applied Microbiology, 85, 178S-185S. https://doi.org/10.1111/j.1365-2672.1998.tb05297.x

[42] Lipponen, M.T.T., Suutari, M.H. and Martikainen, P.J. (2002) Occurrence of Nitrifying Bacteria and Nitrification in Finnish Drinking Water Distribution Systems. Water Research, 36, 4319-4329.

[43] Lipponen, M., Martikainen, P.J., Vasara, R.E., Servomaa, K., Zacheus, O. and Kontro, M.H. (2004) Occurrence of Nitrifiers and Diversity of Ammonia-Oxidizing Bacteria in Developing Drinking Water Biofilms. Water Research, 38, 4424-4434.

[44] Ahonen, M.H., Kaunisto, T., Mäkinen, R., Hatakka, T., Vesterbacka, P., Zacheus, O. and Keinänen-Toivola, M.M. (2008) Suomalaisen talousveden laatu raakavedestä kuluttajan hanaan vuosina 1999-2007. Vesi-Instituutin julkaisuja, 4.

[45] Fleming, K.K., Harrington, G.W. and Noguera, D.R. (2005) Nitrification Potential Curves: A New Strategy for Nitrification Prevention. Journal of the American Water Works Association, 97, 90-99. https://www.awwa.org/publications/journal-awwa/abstract/articleid/15290.aspx

[46] Speitel, G.E., Kannappan, R. and Bayer, B.M. (2011) The Nitrification Index: A Unified Concept for Quantifying the Risk of Distribution System Nitrification. Journal of the American Water Works Association, 103, 69-80. https://www.awwa.org/publications/journal-awwa/abstract/articleid/26680.aspx

[47] Wahman, D.G., Katz, L.E. and Speitel Jr., G.E. (2006) Trihalomethane Cometabolism by a Mixed-Culture Nitrifying Biofilter. Journal of the American Water Works Association, 98, 48-60. https://www.awwa.org/publications/journal-awwa/abstract/articleid/15576.aspx

[48] Crittenden, J.C., Trussell, R.R., Hand, D.W., Howe, K.J. and Tchobanoglous, G. (2005) Water Treatment: Principles and Design. 2nd Edition, John Wiley \& Sons, Inc., Hoboken, NJ. 
Submit or recommend next manuscript to SCIRP and we will provide best service for you:

Accepting pre-submission inquiries through Email, Facebook, LinkedIn, Twitter, etc. A wide selection of journals (inclusive of 9 subjects, more than 200 journals)

Providing 24-hour high-quality service

User-friendly online submission system

Fair and swift peer-review system

Efficient typesetting and proofreading procedure

Display of the result of downloads and visits, as well as the number of cited articles Maximum dissemination of your research work

Submit your manuscript at: http://papersubmission.scirp.org/

Or contact jwarp@scirp.org 